\title{
Lactation, pregnancy and metabolic disorder in the ruminant
}

\section{By G. D. BAIRD, Agricultural Research Council, Institute for Research on Animal Diseases, Compton, Newbury, Berks RG 16 oNN}

When productive demand is high, ruminants are particularly susceptible to the development of signs of carbohydrate insufficiency and adipose tissue mobilization. In the dairy cow and the ewe this occurs most readily during early lactation and late pregnancy, respectively. The signs appear in severe form in the clinicallyrecognizable ketotic disorders of lactational ketosis and pregnancy toxaemia. However, they can also appear to a varying degree in animals that are superficially healthy. The economic importance of this latter phenomenon lies in the apparent relationship between appearance of marked signs of carbohydrate insufficiency or fat mobilization or both and impaired productivity.

The signs probably arise as the result of the interplay of at least three factors. The first of these factors is that priority appears to be accorded to the demands of the lactating mammary gland or conceptus for nutrients, particularly glucose. The second is that in early lactation or late pregnancy voluntary food intake may be limited, and the energy content of the feed consequently insufficient to meet the energy needs for both maintenance and productivity. The third is that the hormonal environment is geared to promote lipid mobilization.

In this review the influence of the three factors will be briefly assessed.

\section{Metabolism in healthy animals}

\section{Lactation}

The dairy cow. In the dairy cow milk production is probably accorded a high degree of metabolic priority in early lactation. Strong support for this view is provided by the fact that most dairy cows experience a period of negative energy balance at this time, when feed intake is insufficient to meet the nutrient requirements for both maintenance and lactation, and maternal tissues have to be mobilized to meet the deficit (Wagner \& Loosli, 1967). The reason for the development of negative energy balance is that, following parturition, milk output rises faster than feed intake (e.g. Owen et al. 1968). The assignment of priority to milk output will ensure that the mammary gland has precedence in its demand for glucose. This is because the rate of uptake of glucose by the gland, per unit weight of milk secreted, is relatively constant in a variety of situations (e.g. Kronfeld et al. 1968).

Although not yet demonstrated unequivocally, it seems probable that developmental (or 'homoeorhetic') hormones, such as prolactin, play a role in ensuring that the metabolic requirements of the mammary gland are met (see $0029-6651 / 81 / 4013-4803$ \$or.00 (C) 1981 The Nutrition Society 
Bauman \& Currie, 1980 ). This role, which is particularly marked in early lactation, consists of increasing the rate of flow of nutrients into the body pool, and of altering the direction of metabolite flux, in order to channel nutrients towards the mammary gland. Some of the effects may be achieved by modulating the action of 'homoeostatic' hormones such as insulin or glucagon. One particular feature of the action of homoeorhetic hormones in early lactation appears to be the encouragement of lipolysis in adipose tissue and lipogenesis in the mammary gland (e.g. Zinder et al. 1974). While glucose is normally able to prevent the in vitro release of non-esterified fatty acids (NEFA) from adipose tissue obtained from dairy cows, it cannot do this when the tissue is obtained in early lactation (Metz \& van den Bergh, 1977).

Another feature of early lactation is that the blood concentration and secretory response of insulin are low (Hove \& Halse, 1978; Lomax et al. 1979). This could be of importance in conferring priority on the glucose demand of the mammary gland, since glucose transport into the gland may not require insulin (e.g. Hove, 1978). The gland could therefore be at an advantage in competing for available glucose with other organs that do require insulin to mediate glucose uptake. The low insulin concentration will also, of itself, encourage lipid mobilization.

When compared with non-lactating animals of the same breed, dairy cows in early lactation show clear signs of carbohydrate insufficiency. These signs include a fall in the circulating concentration of glucose and in the hepatic content of glycogen, and some glucogenic intermediates (Treacher et al. 1976; Baird et al. 1980). This insufficiency presumably arises because glucose turnover, although substantially higher than in the non-lactating state, is still barely sufficient to meet the needs of maintenance and lactation, despite the fact that the maintenance requirement may be diminished. Signs are also evident of adipose tissue mobilization. These include increases in the concentration of NEFA in the blood and of ketone bodies in the blood and liver and also some degree of fatty infiltration of the liver (Treacher et al. 1976; Roberts et al. 1978; Reid et al. 1980). The reasons for this may be twofold. Firstly, the hormonal environment encourages lipid mobilization in early lactation and, secondly, the mobilization may be necessary to provide alternative substrates for glucose.

The fact that, in the dairy cow, the blood concentrations of both glucose and insulin are depressed during lactation suggests that glucose uptake and oxidation by peripheral organs other than the mammary gland is also likely to be depressed at this time. There are a number of observations that support this contention (e.g. Bartley \& Black, 1966; Bennink et al. 1972; Pike \& Roberts, 1980).

The ewe. Glucose turnover is higher in the ewe during lactation than at other times (Bergman \& Hogue, 1967). It might be expected, therefore, that signs of glucose insufficiency would develop in the lactating ewe as they do in the lactating dairy cow. However, this does not seem to be the case. Undoubtedly, one reason for this is that appetite increases rapidly after parturition (e.g. Fell et al. 1972), and marked negative energy balance does not seem to develop. The homoeorhetic drive to lactate is clearly weaker in the ewe than in the dairy cow (see p. 118). 


\section{Late pregnancy}

The ewe. In the pregnant sheep, the foetus has a requirement for glucose that increases sharply towards the end of the gestation period (e.g. Robinson et al. 1971). Despite this, voluntary food intake tends to decline, or at least remain static, as parturition approaches, either because the increase in size of the uterus limits the ability of the rumen to distend, or because other factors that diminish appetite increase in influence at this time (Forbes, 1970). It is clear, therefore, that the latepregnant ewe is likely to have difficulty in matching glucose supply to glucose demand. The situation will be particularly acute when the ewe is bearing multiple foetuses, since uterine volume and demand for glucose will then both be greater. These considerations explain why the healthy late-pregnant ewe may show similar signs of carbohydrate insufficiency and adipose tissue mobilization to those seen in the lactating dairy cow (Blom et al. 1976; Remesy \& Demigne, 1976). However, the changes do not always seem as marked (Herriman et al. 1976). One reason for this is probably that, although depressed, voluntary intake may still be sufficient to ensure approximate energy balance, particularly if appropriate food of high energy density is provided.

For the greater part of pregnancy, adipose tissue deposition is encouraged by a high circulating concentration of insulin and also, possibly, by the dominant influence of progesterone (Flint et al. 1979). During late pregnancy, however, the hormonal environment appears to switch to one that encourages adipose tissue mobilization. This occurs as a result of a fall in insulin concentration, and perhaps an increase in the influence of homoeorhetic hormones, such as oestrogen and placental lactogen, that favour lipolysis (Hove \& Blom, 1976; Chilliard et al. 1978). Recently, the interesting observation has been made that, in the ewe, transport of glucose into the pregnant uterus may not require the mediation of insulin (Prior \& Christenson, 1978). A low concentration of insulin may therefore favour the glucose demand of the pregnant uterus, as it may that of the lactating mammary gland.

The dairy cow. In all probability, the metabolic situation in the late-pregnant cow is similar to that in the late-pregnant ewe, with the exception that cows do not often bear multiple foetuses. Voluntary food intake is low in the cow in late pregnancy, as is blood insulin concentration (Owen et al. 1968; Koprowski \& Tucker, 1973). Reid et al. (1980) demonstrated clear signs of a decrease in carbohydrate sufficiency and an increase in lipid mobilization at one week pre partum in dairy cows.

\section{Glucose and lactate interrelationships}

When compared with non-lactating cows, lactating cows show a switch in the direction of lactate flux across the splanchnic bed (gut and liver taken together). Whereas there is a net outflow of lactate in non-lactating cows at $4-5 \mathrm{~h}$ after feeding, there is a net inflow in the lactating animals (Baird et al. 1980). This switch, which appears to be another indication of diminished carbohydrate 
sufficiency, occurs because the rate of uptake, and percentage extraction, of lactate by the liver is greater during lactation.

In recent collaborative research (J. G. van der Walt, E. N. Bergman and G. D. Baird, unpublished work), net exchange of both lactate and glucose across gut, liver and hind-quarters has been monitored in ewes through late pregnancy and into lactation. In late pregnancy the pattern of lactate exchange across gut and liver was similar to that previously observed in lactating cows, and lactate was released from the hind-quarters. By contrast, the situation during lactation was intermediate between that seen in lactating and non-lactating cows. In particular, hepatic lactate extraction was significantly less in the sheep when they were lactating than when they were late-pregnant.

It could be concluded, therefore, that the sheep showed more indication of carbohydrate insufficiency during late pregnancy than during lactation. This conclusion was reinforced by the observation that blood glucose concentration was lower during pregnancy. It was further observed that glucose uptake by the hind-quarters was lower during pregnancy, while lactate release from the hind-quarters, expressed as a percentage of glucose uptake, was higher. The latter findings provide support for the concept that diminished carbohydrate sufficiency entails a decrease in the ability of peripheral organs, other than those involved in the productive process, to extract energy and carbon from blood glucose.

Studies using tracer infusions demonstrated that the extent to which glucose was converted to lactate, and lactate was converted to glucose, was greater in the sheep during late pregnancy than during lactation. A high level of interconversion of glucose and lactate is, therefore, another feature of diminished carbohydrate sufficiency.

\section{Ketosis}

\section{During lactation}

The dairy cow. The three factors that are involved in the development of signs of carbohydrate insufficiency and lipid mobilization in healthy cows in early lactation must also be involved in the development of spontaneous bovine ketosis. This is clear from the observations that ( 1 ) the biochemical changes occurring in association with spontaneous ketosis are merely an extreme manifestation of the signs of energy deficiency already evident in the healthy animals; and (2) cows are only susceptible to the disorder during early lactation, when the homoeorhetic stimulus to lactate is at a maximum (e.g. Baird, 1977). Spontaneous ketosis probably arises, therefore, because the susceptible cow attempts to maintain milk output in the face of a serious deficiency in glucose supply. This then results in a fall in blood glucose concentration, rapid lipid mobilization and severe hyperketonaemia. This view receives strong support from experiments designed to test the response of lactating cows to a few days of fasting. Animals that are within the period of susceptibility to spontaneous ketosis become severely hypoglycaemic and hyperketonaemic, while those outside this period do not. The reason for the 
difference appears to be that during the fast milk production falls more slowly in the susceptible cows (Baird et al. 1972).

The ewe. Spontaneous ketosis in lactating sheep is unknown, in non-dairy breeds at least. Presumably, any deficiency in glucose supply will be met in the extreme case by cessation of lactation. Non-lactating, non-pregnant sheep, or cows, are remarkably resistant to the development of fasting-induced ketosis (Herriman \& Heitzman, 1978; Baird et al. 1979).

\section{During pregnancy}

The ewe. Once again, the biochemical changes seen in pregnancy toxaemia in the ewe appear to be an extreme manifestation of the signs of energy deficiency seen in healthy animals in late pregnancy, and presumably therefore have a common aetiology. This conclusion is supported by the fact that the disorder only occurs in late pregnancy and then usually in multifoetate animals. The precipitating cause is normally a decline in the quality or quantity of feed intake, leading to a deficiency in glucose supply, although stress factors may also play a part (e.g. Reid, ig68). The pregnant sheep is in a particularly difficult situation, since, although it may be diminished (Battaglia \& Meschia, 1978), the glucose drain to the uterus cannot be halted unless the foetuses are aborted or die in utero.

The cow. Pregnancy toxaemia is rare in dairy cows, presumably because these animals usually bear single foetuses. However, the disorder can occur in cows if feed intake decreases sufficiently. Caple et al. (1977) have reported the occurrence of pregnancy toxaemia in beef cattle that were obliged to graze inadequate pasture in late pregnancy. Cows bearing twins were particularly susceptible.

\section{Impaired productivity}

As an example, there have been a number of reports that a high level of milk production or a low level of energy intake can lead to diminished fertility in dairy cows (e.g. Lamond, 1970). In both these situations there are likely to be marked indications of carbohydrate insufficiency and adipose tissue mobilization. This suggests that appearance of these features may have an adverse effect on fertility. Some workers have proposed that a low blood glucose concentration and a decrease in availability of glucose to peripheral organs, presumably within the hypothalamo-pituitary-gonadal axis (e.g. Leathem, 1966) is the crucial feature (Oxenreider \& Wagner, 1971; McClure et al. 1978). An alternative hypothesis is that fatty infiltration of the liver, and consequent impairment of liver function is of importance (Reid et al. 1979).

\section{REFERENCES}

Baird, G. D. (1977). Biochem. Soc. Trans. 5, 819.

Baird, G. D., Heitzman, R. J. \& Hibbitt, K. G. (1972). Biochem. J. 128, I3I I.

Baird, G. D., Heitzman, R. J., Reid, I. M., Symonds, H. W. \& Lomax, M. A. (1979). Biochem. J. 178,35 .

Baird, G. D., Lomax, M. A., Symonds, H. W. \& Shaw, S. R. (1980). Biochem. F. 186, 47.

Bartley, J. C. \& Black, A. L. (I966). F. Nutr. 89, 317. 
Battaglia, F. C. \& Meschia, G. (1978). Physiol. Rev. 58, 499.

Bauman, D. E. \& Currie, W. B. (1980). F. Dairy Sci. 63, 1514.

Bennink, M. R., Mellenberger, R. W., Frobish, R. A. \& Bauman, D. E. (1972). J. Dairy Sci. 55, 712.

Bergman, E. N. \& Hogue, D. E. (1967). Am. J. Physiol. 213, I 378.

Blom, A. K., Hove, K. \& Nedkvitne, J. J. (1976). Acta Endocrinol. 82, 553.

Caple, I. W., Pemberton, D. H., Harrison, M. A. \& Halpin, C. G. (1977). Aust. Vet. F. 53, 289.

Chilliard, Y., Durand, G., Sauvant, D. \& Morand-Fehr, P. (1978). C. R. Acad. Sci. Paris Ser. D. 287, II 3 I.

Fell, B. F., Campbell, R. M., Mackie, W. S. \& Weekes, T. E. C. (1972). f. agric. Sci., Camb. 79, 397 .

Flint, D. J., Sinnett-Smith, P. A., Clegg, R. A. \& Vernon, R. G. (1979). Biochem. J. 182, 421.

Forbes, J. M. (1970). F. Anim. Sci. 31, 2222.

Herriman, I. D. \& Heitzman, R. J. (I978). F. agric. Sci, Camb. 90, 579.

Herriman, I. D., Heitzman, R. J., Preistley, I. \& Sandhu, G. S. (1976). F. agric. Sci., Camb. 87, 407 .

Hove, K. (1978). Acta Physiol. Scand. 103, r 73.

Hove, K. \& Blom, A. K. (r976). Acta Endocrinol. 82, 544 .

Hove, K. \& Halse, K. (1978). Acta Vet. Scand. 19, 2 I 5.

Koprowski, J. A. \& Tucker, H. A. (1973). Endocrinol. 93, 645.

Kronfeld, D. S., Raggi, F. \& Ramberg, C. F. (1968). Am. f. Physiol. $215,218$.

Lamond, D. R. (1970). Anim. Breed. Abstr. 38, 359.

Leathem, J. H. (1966). F. Anim. Sci. 25, (Suppl. 1), 68.

Lomax, M. A., Baird, G. D., Mallinson, C. B. \& Symonds, H. W. (1979). Biochem. F. 180, 28 I.

McClure, T. J., Nancarrow, C. D. \& Radford, H. M. (1978). Aus. Y. biol. Sci. 31, 183.

Metz, S. H. M. \& van den Bergh, S. G. (1977). Neth. Y. agric. Sci. $25,198$.

Owen, J. B., Miller, E. L. \& Bridge, P. S. (rg68). f. agric. Sci., Camb. 70, 223.

Oxenreider, S. L. \& Wagner, W. C. (1971). F. Anim. Sci. 33, 1026.

Pike, B. V. \& Roberts, C. J. (1980). Res. Vet. Sci. 29, 108.

Prior, R. L. \& Christenson, R. K. (1978). J. Anim. Sci. 46, 201.

Reid, I. M., Roberts, C. J. \& Baird, G. D. (1980). F. agric. Sci., Camb. 94, 239.

Reid, I. M., Roberts, C. J. \& Manston, R. (1979). Vet. Rec. 104, 75.

Reid, R. L. (1968). Adv. Vet. Sci. 12, 163.

Remesy, C. \& Demigne, C. (1976). Ann. Rech. Vet. 7, 329.

Roberts, C. J., Reid, I. M., Dew, S. A., Stark, A. J., Baird, G. D., Collins, R. A. \& Mather, D. (1978). F. agric. Sci., Camb. 90, 383 .

Robinson, J. J., Fraser, C. \& Bennett, C. (1971). f. agric. Sci., Camb. 77, 14 I.

Treacher, R. J., Baird, G. D. \& Young, J. L. (1976). Biochem. F. 158, 127.

Wagner, D. G. \& Loosli, J. K. (1967). Memoir 400, N.Y. Agric. Exp. Stn. Ithaca, N.Y., USA.

Zinder, O., Hamosh, M., Fleck, T. R. C. \& Scow, R. O. (1974). Am. F. Physiol. 226, 744. 